\title{
Transition from Modernism to Postmodernism in Urban Planning and Architecture
}

\author{
Yinuo Zhao \\ Urban Construction School, Beijing City University, Beijing 100000, China \\ DOI: $10.32629 /$ aes.v2i4.540
}

\begin{abstract}
From the middle of the 20th century to the end of the 20th century, modernism made its transition to postmodernism in a gradual manner. This paper, starting from the connotation of modernism to postmodernism, sorts out the main evolution and transition of modernism and modernism in the field of urban planning and architecture. Later on, analysis is made in this paper on the difference and complementarity from modernism to postmodernism and discusses the contemporary continuity of its spirit.
\end{abstract}

Keywords: modernism, postmodernism, transformation, planning and architecture

As the Western society experienced the Industrial Revolution and the Two World Wars to the middle of the 20th century, the modernism movement also experienced a stage of emergence, development and climax. Until the 1960s, the modernism thought gradually made its transition to postmodernism. Postmodernism is a critique of the increasingly conflicting issues arising from the rationalist spirit at the core of modernism. In light of the times, postmodernism is the "extension" of modernism. From the historical background, modernism is developed based on the mechanization of the early industrial revolution, while post-modernism gained momentum based on the social information and the compression of time and space. In terms of its development process, postmodernism sprouted and developed in the crisis generated in the development of modernism ${ }^{[1]}$.

The transition from modernism to postmodernism is an inevitable historical development, which has a far-reaching influence on the ideology, urban development, architectural thoughts, art and culture of the eastern and western societies. In terms of urban planning and architectural thought, this paper sorts out the main transformation from modernism to postmodernism from the middle of the 20th century to the end of the 20th century, and makes analysis on the reasons for the different situations of postmodernism in the field of contemporary urban planning and architecture and its enlightenment to China.

\section{The main evolution and transition from modernism to postmodernism}

Since the western countries entered the industrial age in the 19th century, society has been developing and changing in various fields. The application of new technology, new materials and new technology enables architecture to reach a height and span that classical architecture has never reached, showing the infinite creativity of human beings and the courage to build a new world, and becoming a prelude to the emergence of modernism. After the first World War in the 20th century, the modernism movement gradually emerged and developed under the background of the "Machine Age" of mechanized mass production. Modernism embraces scientific and technological progress and is an idea dominated by western society in the context of the industrial age, with rationalism as its core. Experts in various fields lead the progress and development of society in their fields as intellectual elites. With the end of the Second World War, the rationality and pragmatism of modernism, as well as the strong sense of urgency of post-war reconstruction reflected the strong adaptability and radical spirit of the times. At this point, the strict and feasible practical methods of modernism formed a rational paradigm and were widely used, and the modernism movement reached its climax.

As people reflect on the contradictions and problems arising from the rapid development of modernism, modernism started to transform to postmodernism in the 1960s. The relationship between postmodernism and modernism showed both differences and pertinence. The transition from modernism to postmodernism is mainly reflected in its core spirits and value mode. It is a process of critical deconstruction and transformation of the rational value model of modernism. It is a process from the single modernism to the pluralism of postmodernism, from the blueprint of rationalism to the process of contextualism, and from the high speed to the high quality. It calls for the relativism inclusiveness and open thinking of the pluralistic values of human culture. 


\section{Modernism to postmodernism in the field of urban planning and architecture}

\subsection{The transition from modernist urban planning to post-modernist urban planning}

In the whole history of urban planning, from the perspective of development and evolution, western urban planning theory has gone through three important stages ${ }^{[2]}$. From the "Garden City" theory of British social activist Howard at the end of 19th century in 1898 to the establishment of the rationalist thought of Athens Charter in 1933 during the period of modernism, urban planning is a prelude from material form planning to rational planning. From then on to the 1960s, it was the first stage of rational planning of western cities in the modernism period, which guided postwar urban reconstruction and rapid urban development with rational planning paradigm and planning method system. Its emergence and development were deeply influenced by modernist architecture. In this stage, it can be said that architects played a foundational role in the first stage of rational planning of modern cities.

For example, the "Glorious City" theory represented by Le Corbusier in 1931 and the urban planning practice of Chandigarh in 1951. Since from the 1960s to the end of the twentieth century, is a modern socialist to postmodernism urban planning, urban planning is the modern urban planning from a rational planning to advocate the type of the second stage, is faced with modernism cities rapid development increasingly conflict problem period of reflection and criticism, is also a important turning point in moving towards a new era. The relationship between urban planning and architecture in this stage and its later stages is gradually becoming more and more distant, which is the transformation of urban planning from architectural thinking to social science and the exploration of the essence of urban planning. For example, The Death and Life of Great American Cities by Jacob in 1961 and A City is Not a Tree by Alexander in 1965 were both critical and reflective of modernist urban issues and explorations of urban essence in the post-modernism period. The Charter of Machu Picchu in 1977 formally raised the rebellious program of post-modernism urban planning.

Table 1. Main transition from modernism to postmodernism in urban planning

\begin{tabular}{lll}
\hline \multicolumn{1}{c}{ Transition } & \multicolumn{1}{c}{ Modernism } & Postmodernism \\
\hline Process & $\begin{array}{l}\text { Utopia, the idealized architectural } \\
\text { thinking of urban structure }\end{array}$ & $\begin{array}{l}\text { Based on the criticism of contradiction in modernism urban } \\
\text { problem }\end{array}$ \\
Value orientation & $\begin{array}{l}\text { The physical environment at the } \\
\text { rationalist level of physical space }\end{array}$ & $\begin{array}{l}\text { The transformation of humanistic places in humanistic } \\
\text { spirit }\end{array}$ \\
& $\begin{array}{l}\text { 1 Rationalism } \\
\text { 2 effectiveness } \\
\text { 3 Science and art } \\
\text { 4 Government dominance } \\
\text { 5 Public interest }\end{array}$ & $\begin{array}{l}\text { 1. Social justice } \\
\text { 2. Discussion on multi-stakeholder } \\
\text { 3. Civilianism }\end{array}$ \\
& $\begin{array}{l}\text { Elite rationalism blueprint urban } \\
\text { planning }\end{array}$ & $\begin{array}{l}\text { The democratic nature of progressive and advocacy civic } \\
\text { participation and the transition to public policy }\end{array}$ \\
\hline
\end{tabular}

The transition from modernism to postmodernism means transition of values of materials based on rationalism to spiritual level based on humanism, which is a transition of thought of a subjective "man-made civilized city" to democratic "multi-urban civilization". But modernism to postmodernism urban planning is not completely opposite, it has a certain complement and continuity, showing more complex and contradictory pluralistic value orientation.

\subsection{The transition from modernism to postmodernism}

At the beginning of the 20th century, modernist architecture was pioneered in 1913 by the architect Adolf Luce in an article entitled "Ornament and Crime". Its expression forms are derived from the pursuit of rational use of space, which is the core essence of functionalism of "form follows function" proposed by Sullivan ${ }^{[3]}$. After the first World War, modernist architecture stepped onto the stage of history. In 1926, le Corbusier took "the house is the living machine" as his architectural declaration and proposed "five characteristics" of modern architecture for his residential design: stilted bottom pillar, roof garden, free plane, free facade and transverse long window. Villa Savoy is the concentrated embodiment of his thoughts. At the same time, German architect Mies also proposed his new architectural concept of "less is more", and his concept of "flowing space" was applied to the German Pavilion in Barcelona. After the Second World War, the trend of thought of "modern architecture" was widely applied in European and American countries, forming the "internationalism style" and pushing modernist architecture to a climax. Until the 1960s, modernist architecture began to be questioned and turned to post-modernist architecture. From the historical development of architecture, there is a huge deviation in modernist archi- 
tecture, which is essentially the product of capitalist economic development to a certain period and neglects the essential factors of human beings.

Since the emergence of post-modern architecture, its architectural concept presents a vague sense. Every postmodern building has some self-metaphor that inspires a link between the viewer and the building. It can be said that postmodern architecture is more of a critique of the functionalism of modernist architecture. In 1966, The Complexity and Contradiction in Architecture by Venturi became the symbol of the birth of postmodernist architectural thought, and his work "Mother's House" became the first postmodernist architectural work.

Table 2. Main transition from modernism to post-modernism architecture

\begin{tabular}{lll}
\hline Transition & \multicolumn{1}{c}{ Modernism } & \multicolumn{1}{c}{ Postmodernism } \\
\hline School & Functionalism, international style & $\begin{array}{l}\text { Various schools after modernism: post-modernism, deconstruction, new } \\
\text { modernism, high-tech and so on }\end{array}$ \\
Concept & Less is more, reductionist style & A decorative reductionist style opposing missis in which less is more \\
Core value & Rationalism, functionalism & A history of diverse cultures \\
Methods & $\begin{array}{l}\text { The practical method of rational } \\
\text { functionalism }\end{array}$ & Collage evolution of classical symbols \\
\hline
\end{tabular}

The transition from modernist architecture to postmodern architecture is a transition from international style to style language that breaks the boundaries of nations and countries. It is a kind of cross-cultural communication that can be realized. It is a turn from functional rationalism to regional culture.

\section{Different situations of postmodernism in the field of contemporary urban plan- ning and architecture}

In the field of urban planning, the end of the 20th century is the third stage of the development of urban planning theory, which is a new pattern of collaborative planning with diversified development and people-oriented sustainable development concept $\mathrm{t}^{[4]}$. Although the transition from modernist urban planning to "post-modernity" became inevitable in the $1960 \mathrm{~s}$, post-modernist urban planning was not a complete negation of modernist thoughts and systematic methods, but a critical supplement through which it took root and germinated. Up to now, in the field of contemporary urban planning, the pluralism of the core essence of postmodernism urban planning has not been abandoned. Neither the new urbanism advocacy planning nor the collaborative sustainable planning has abandoned the postmodernism spirit and is still in practice and discussion ${ }^{[5]}$.

In the field of architecture, postmodern architecture falls into an extreme. On the one hand, postmodern architecture tries to reflect certain historical elements in architectural language, i.e. architectural symbols, architectural proportions and materials. When using these historical elements, postmodern architecture only takes fragments of history or combines historical elements of different periods, and adopts a compromise way to express design ideas, without considering the relationship between architecture and regional environment, architecture and urban context. Postmodern architecture is reduced to an embarrassment of style expression. Postmodern architecture should be the embodiment of the spirit of the times, but its essential core has not undergone a fundamental change, and its style has not been continued up to now.

The transition from modernism to postmodernism in the field of urban planning and architecture and the evolution of the current situation can be seen as an important transition and an epitome of the times in the process of western modern cities. The breadth and depth of its content is transformed into the study of the connotation of the contemporary city itself, drawing experience from the western urban planning and architecture theory and practice, and its contemporary nature promotes the better development of Chinese cities.

\section{$\underline{\text { References }}$}

[1] Xu Chan, Wen Tianzuo, Huang Baiwei, Xiang Lanlin. Urban planning from the perspective of postmodernism and its enlightenment to China[J]. Modern Urban Research, 2016(04):2-9.

[2] Zhang Tingwei. Urban construction in the 21st century under the guidance of planning Theory in the 20th century Discussion on the "Third Generation Planning Theory"[J]. Urban Planning Forum, 2011(03):1-7.

[3] Wang Zheng. Form Follows Function: The Misinterpretation of american organic functionalism[J]. The Architect, 
2012(06):14-21.

[4] Yang Baojun. Review and prospect of urban planning in the past 30 years[J]. Urban Planning Forum, 2010(01):14-23.

[5] Cao Yang, Zhang Yan. Postmodern Planning: The contemporary continuation of postmodern spirit -- From Lin Shaowei's Book Asian Ethical Urbanism -- A Radical Postmodern Perspective[J]. Architecture and Culture, 2013(12):92-93. 